\title{
Relative importance of dissolved versus trophic bioaccumulation of copper in marine copepods
}

\author{
Sung Il Chang, John R. Reinfelder* \\ Department of Environmental Sciences, Rutgers University, 14 College Farm Road, New Brunswick, New Jersey 08901, USA
}

\begin{abstract}
In order to evaluate the relative contribution of water and food to the accumulation of copper in herbivorous marine zooplankton, the accumulation and loss rates of $\mathrm{Cu}$ in coastal copepods (Acartia sp. and Temora sp.) were measured and applied to a kinetic bioaccumulation model. Experiments were performed to measure stable $\mathrm{Cu}$ uptake from the dissolved phase in field-collected copepods acclimated for 2 to $3 \mathrm{~d}$ to a low $\mathrm{Cu}$ diet. The copepods were exposed to a range of free- $\mathrm{Cu}$ ion concentrations $\left(\left[\mathrm{Cu}^{2+}\right]=10^{-14.8} \mathrm{M}, 10^{-12.8} \mathrm{M}, 10^{-9.8} \mathrm{M}\right)$, but a significant $\mathrm{Cu}$ accumulation rate was only observed in copepods exposed to $10^{-9.8} \mathrm{M} \mathrm{Cu}^{2+}$. Based on the $\mathrm{Cu}$ uptake rate measured at $10^{-9.8} \mathrm{M} \mathrm{Cu}^{2+}$, a free ion-specific uptake rate constant of dissolved $\mathrm{Cu}$ of $1.1 \times 10^{4} \mathrm{l} \mathrm{g}^{-1} \mathrm{~d}^{-1}$ was estimated. Efflux rate constants of $\mathrm{Cu}$ in copepods estimated from depuration experiments were $0.056 \pm$ 0.016 and $0.076 \pm 0.012 \mathrm{~d}^{-1}$ in laboratory-fed and unacclimated copepods, respectively. Application of these $\mathrm{Cu}$ uptake and efflux parameters, and those for $\mathrm{Cu}$ trophic transfer from previous studies, to a kinetic bioaccumulation model shows that food is the dominant source of $\mathrm{Cu}$ ( $>75 \%$ of total accumulation) at free- $\mathrm{Cu}$ ion concentrations ranging from $10^{-14.8}$ to $10^{-11.8} \mathrm{M}$. At free-Cu concentrations $\geq 10^{-11.8} \mathrm{M}$, dissolved uptake becomes a significant portion ( $>20 \%$ ) of total $\mathrm{Cu}$ accumulation accounting for almost $60 \%$ of the total $\mathrm{Cu}$ in copepods at $10^{-9.8} \mathrm{M} \mathrm{Cu}^{2+}$. These results suggest that herbivorous marine zooplankton accumulate $\mathrm{Cu}$ mainly by trophic transfer, but that dissolved uptake could be important in contaminated waters.
\end{abstract}

KEY WORDS: Copper - Bioaccumulation - Dissolved uptake - Kinetic model · Zooplankton · Copepods

\section{INTRODUCTION}

The bioavailability and trophic transfer of metals in aquatic food chains has received considerable attention in recent years (Wang et al. 1996, Fisher et al. 2000, Lee et al. 2000) in an effort to better understand the geochemical cycling of metals and the nutritional and toxicological effects of metals in aquatic organisms. A quantitative analysis of the pathways of metal bioaccumulation is also important to the development of water quality criteria, since levels based only on dissolved metal concentrations in natural waters and sediments may not be appropriate to assess the full extent and im-

${ }^{*}$ Corresponding author. E-mail: reinfelder@envsci.rutgers.edu pact of metal contamination in aquatic environments. For many aquatic invertebrates, metal accumulation from ingested food is the main route of overall bioaccumulation (Luoma et al. 1992, Fisher \& Reinfelder 1995, Wang et al. 1996, Munger \& Hare 1997). The bioavailability of metals associated with food particles can therefore be important to the assessment of the potential impacts of metal contamination in such organisms.

The relative importance of dissolved versus trophic accumulation of metals in herbivorous zooplankton depends on the chemical properties of each metal and the physiology and activity of the zooplankton. These geochemical and biological properties can be used to quantify the 2 routes of accumulation separately in a bioenergetic-based kinetic model. Essential information includes accumulation rates of ingested metals, 
uptake rates for the dissolved phase, and depuration rates of metals in consumer animals (Landrum et al. 1992, Thomann et al. 1995, Wang \& Fisher 1997). Kinetic bioaccumulation models have been applied to the bioavailability and trophic transfer of a variety of essential (Co, Se, and $\mathrm{Zn}$ ) and non-essential (Ag, Am, $\mathrm{Cd}$, and $\mathrm{Hg}$ ) trace metals in copepods (Wang \& Fisher 1998, Fisher et al. 2000), mussels (Wang et al. 1996, Wang \& Fisher 1997), and other marine and freshwater animals. These efforts have been supported by substantial data on the bioaccumulation of such metals in marine phytoplankton and aquatic herbivore organisms (Fisher \& Reinfelder 1995). However, despite its potential toxicity and elevated concentrations in impacted coastal waters (Moffett et al. 1997), Cu has been little studied with regard to its bioaccumulation by herbivorous zooplankton or other marine consumers (Chang \& Reinfelder 2000). There is an indication that $\mathrm{Cu}$ concentrations in some polluted estuarine waters are high enough to affect the survival and production of marine copepods (Sunda et al. 1987), but a quantitative study of the pathways of $\mathrm{Cu}$ accumulation in such marine herbivores has not been done. The paucity of data may be due to the lack of a readily available, long-lived $\mathrm{Cu}$ radioisotope or a stable isotope of low mass abundance.

Our objectives were to measure $\mathrm{Cu}$ influx and efflux rates in marine copepods and to determine the relative importance of dissolved and trophic pathways to overall $\mathrm{Cu}$ bioaccumulation. With the use of trace metal clean culture techniques and trace-metal-buffered seawater, we attempted to measure gross uptake and loss rates of stable $\mathrm{Cu}$ in copepods. Another objective was to relate $\mathrm{Cu}$ accumulation in copepods to the concentration of free $\mathrm{Cu}^{2+}$, which is proportional to that of total inorganic $\mathrm{Cu}$ and represents the bioavailable pool. Copper accumulation and toxicity in marine phytoplankton (Sunda \& Guillard 1976, Anderson \& Morel 1978, Sunda \& Huntsman 1983) and invertebrates (Zamuda \& Sunda 1982, Sanders et al. 1983, Sunda et al. 1987) has been related to the free-Cu ion concentration, and mechanistic relationships between $\mathrm{Cu}$ accumulation and free or kinetically labile $\mathrm{Cu}$ pools have been inferred. It is not known which chemical species of $\mathrm{Cu}$ are taken up by copepods, but since deleterious effects were observed at free- $\mathrm{Cu}$ concentrations of $10^{-10}$ to $10^{-11} \mathrm{M}$ (Sunda et al. 1987, Sharp \& Stearns 1997), we measured $\mathrm{Cu}$ accumulation over the range of $10^{-14.79}$ to $10^{-9.79} \mathrm{M}$.

\section{MATERIALS AND METHODS}

Diatom cultures. Axenic cultures of the marine diatom Thalassiosira weissflogii (Actin) were main- tained in trace-metal-buffered artificial seawater media (Aquil, Price et al. 1988/89) under continuous $(24 \mathrm{~h})$ illumination $\left(200 \mu \mathrm{mol}\right.$ quanta $\left.\mathrm{m}^{-2} \mathrm{~s}^{-1} \mathrm{PAR}\right)$ at $18^{\circ} \mathrm{C}$. In these culture media, which include macronutrients ( $\mathrm{N}, \mathrm{P}$, and $\mathrm{Si})$, vitamins, and trace metals, the concentrations of free and inorganic trace metal pools are maintained constant by excess concentrations of the chelating agent EDTA (ethylenediaminetetraacetic acid). Free-Cu ion concentrations were controlled by adding a 1:1 (mol:mol) Cu:EDTA solution (Sunda \& Huntsman 1995, Chang \& Reinfelder 2000). Speciation calculations of trace-metal concentrations in the media were made using the MINEQL speciation program (Westall et al. 1976).

Copepods. Copepods were collected with a plankton net (63 $\mu \mathrm{m}$ Nylon mesh) from Cheesequake Creek near Raritan Bay, New Jersey, USA. Immediately following collection, adult copepods were separated from nauplii by sieving with a $350 \mu \mathrm{m}$ Nylon netting and transferred to Cheesequake Creek water $(S=24)$ that had been passed through $20 \mu \mathrm{m}$ Nylon mesh. Microscopic examination showed that the mixed assemblage contained $\sim 90 \%$ Acartia sp. and $\sim 10 \%$ Temora sp. (by number). Thus while the results obtained here are not strictly species-specific, they are most representative of $\mathrm{Cu}$ interactions with Acartia sp. Copepods were acclimated in diluted, trace-metal-free synthetic ocean water (SOW, $S=25$ ) at $18^{\circ} \mathrm{C}$ for 2 or $3 \mathrm{~d}$ prior to $\mathrm{Cu}$ uptake experiments, during which time they were fed the diatom Thalassiosira weissflogii grown at $\mathrm{pCu} 14.8$ $\left(\mathrm{pCu}=-\log \left[\mathrm{Cu}^{2+}\right]\right)$.

Copper uptake in copepods from the dissolved phase. Experiments were performed to examine timedependent copper uptake from the dissolved phase into marine copepods over a range of free- $\mathrm{Cu}$ ion concentrations ( $\mathrm{pCu}=14.79$ to 9.79). The EDTA-buffered $\mathrm{Cu}$ uptake media were prepared exactly as those for the diatom cultures, including $0.2 \mu \mathrm{m}$ filtration, except that the SOW was diluted to $S=25$ to minimize the possible effects of salinity change on metal uptake and copepod physiology. The same concentrations of macro-nutrients ( $\mathrm{N}, \mathrm{P}$, and $\mathrm{Si})$, vitamins, EDTA, and other micro-nutrient trace elements $(\mathrm{Zn}, \mathrm{Fe}, \mathrm{Mo}$, and Se) as used in the diatom culture media were added to the copepod uptake media. After adding a 1:1 (mol:mol) Cu:EDTA solution, the uptake media were equilibrated for at least $24 \mathrm{~h}$ at $18^{\circ} \mathrm{C}$ prior to the experiments. The trace metal speciation calculations for the diluted Aquil media are presented in Table 1. Copepods in the acclimation media were collected on a $350 \mu \mathrm{m}$ Nylon netting and transferred to uptake media in a plastic beaker. This media was then divided into small plastic bottles, each of which held 50 to 60 individual copepods in $40 \mathrm{ml} \mathrm{Cu}$ uptake media. These bottles were maintained at $18^{\circ} \mathrm{C}$ in the dark for 8 to $24 \mathrm{~h}$. 
Table 1. Total metal concentrations required to achieve specified free metal concentrations $\left(\mathrm{pM}=-\log \left[\mathrm{M}^{\mathrm{z}}\right]\right)$ in diluted salt $(S=25)$ Aquil media. Metal speciation calculated with MINEQL (Westall 1976)

\begin{tabular}{|lcr|}
\hline Metal & Total concentration $(\mathrm{M})$ & $\mathrm{pM}$ \\
\hline $\mathrm{Cu}$ & $3.05 \times 10^{-9}$ & 14.79 \\
& $3.05 \times 10^{-7}$ & 12.79 \\
$\mathrm{Fe}$ & $3.05 \times 10^{-4}$ & 9.79 \\
$\mathrm{Mn}$ & $8.32 \times 10^{-6}$ & 18.70 \\
$\mathrm{Zn}$ & $1.21 \times 10^{-7}$ & 8.42 \\
& $7.97 \times 10^{-8}$ & 11.07 \\
\hline
\end{tabular}

At each sampling time, copepods were separated from uptake media using a $350 \mu \mathrm{m}$ Nylon netting and transferred to $10 \mathrm{ml}$ trace-metal-free $\mathrm{SOW}$ in a plastic beaker. The copepods were then collected on preweighed $3 \mu \mathrm{m}$ polycarbonate membrane filters and sequentially rinsed with $10 \mathrm{ml}$ of $1 \mathrm{mM}$ EDTA in tracemetal-free SOW and $10 \mathrm{ml}$ of SOW to remove adsorbed $\mathrm{Cu}$ from the surfaces of the copepods. The copepods were also rinsed with $10 \mathrm{ml}$ of $0.7 \mathrm{~N}$ ammonium formate to remove inorganic sea-salts. The filter with copepods was dried at $60^{\circ} \mathrm{C}$ overnight and weighed with a microelectronic balance (copepod dry weight $=$ $7.51 \times 10^{-3} \mathrm{mg}$ per individual copepod).

Efflux rates of copper from laboratory-fed and unacclimated copepods. Laboratory-fed copepods were fed diatoms grown in Aquil as described above, except that the free- $\mathrm{Cu}$ ion concentration was $10^{-12.79} \mathrm{M}$. Mid-exponential growth phase cells (cell densities of $5-7 \times 10^{4} \mathrm{cells} \mathrm{ml}^{-1}$ ) were collected on $3 \mu \mathrm{m}$ polycarbonate (PC) membrane filters and rinsed sequentially with $10 \mathrm{ml}$ of $1 \mathrm{mM}$ EDTA in trace-metalfree SOW and $10 \mathrm{ml} \mathrm{SOW}$ to remove adsorbed $\mathrm{Cu}$ from the cell surfaces. Diatoms were resuspended in $500 \mathrm{ml}$ of diluted $(S=25) \mathrm{SOW}$ in a $500 \mathrm{ml} \mathrm{PC}$ bottle and 600 to 700 copepods were added. The feeding suspension was maintained at $18^{\circ} \mathrm{C}$. After $1 \mathrm{~d}$ of feeding, the copepods were collected on a $350 \mu \mathrm{m}$ Nylon netting, rinsed with SOW, and transferred to $100 \mathrm{ml}$ of particle-free (0.2 $\mu \mathrm{m}$ filtered) SOW and allowed to clear their guts for $1 \mathrm{~h}$. They were then transferred to $500 \mathrm{ml}$ of particle-free SOW and allowed to depurate in the absence of food for $2 \mathrm{~d}$ at $18^{\circ} \mathrm{C}$. At each sampling time, 50 to 60 individual copepods were removed from the bottle by filtering $40 \mathrm{ml}$ of depuration media through a $350 \mu \mathrm{m}$ Nylon mesh. After transferring the copepods to $30 \mathrm{ml}$ of SOW, they were immediately collected on preweighed $3 \mu \mathrm{m}$ PC membrane filters and rinsed with $10 \mathrm{ml}$ of $0.7 \mathrm{~N}$ ammonium formate solution to remove inorganic salts. The filter with the copepods was dried at $60^{\circ} \mathrm{C}$ overnight and weighed with a microelectronic balance. Additional experiments were conducted to examine the efflux rates of copper from copepods that accumulated $\mathrm{Cu}$ from the dissolved phase and by trophic transfer in their natural environment (unacclimated copepods). For these studies, freshly collected copepods were immediately transferred to the diluted SOW and allowed to depurate $\mathrm{Cu}$ in the absence of food for $3 \mathrm{~d}$ at $18^{\circ} \mathrm{C}$.

The rates with which trace metals are eliminated from aquatic invertebrates show first-order dependence on the concentration of the metal in the organism (Reinfelder et al. 1997, Wang \& Fisher 1998). The efflux of $\mathrm{Cu}$ from copepods was therefore fit to a firstorder, exponential loss model in order to calculate $\mathrm{Cu}$ loss rate constants:

$$
\mathrm{Cu}_{t}=\mathrm{Cu}_{0} \mathrm{e}^{-k t}
$$

where $\mathrm{Cu}_{t}$ is the concentration of $\mathrm{Cu}\left(\mu \mathrm{g} \mathrm{g}{ }^{-1}\right.$ dry wt) retained in the copepods at time $t(\mathrm{~d}), \mathrm{Cu}_{0}$ is the initial $\mathrm{Cu}$ concentration in the copepods, and $k$ is the $\mathrm{Cu}$ efflux rate constant $\left(\mathrm{d}^{-1}\right)$.

Sample digestion and $\mathbf{C u}$ analysis. For sample digestion, PC filters with copepods were placed in $30 \mathrm{ml}$ fused-quartz crucibles and $3 \mathrm{ml}$ concentrated nitric acid (OPTIMA grade, Fisher) was added. After $2 \mathrm{~d}$ incubation at room temperature, filters were removed and the solution was slowly evaporated on a hot plate at $90^{\circ} \mathrm{C}$. Copper in the residue was extracted with $1 \mathrm{ml}$ of $1 \%$ nitric acid (OPTIMA grade), and the extract was transferred to a $1.25 \mathrm{ml}$ acid-cleaned, micro-centrifuge tube. The sample was centrifuged at $12000 \times g$ for $3 \mathrm{~min}$ at room temperature to spin down any particles in the extract and copper concentrations in the supernatant were determined by graphite furnace atomic absorption spectrometry (GFAAS, PerkinElmer 4100 ZL) using an external calibration method. Quality assurance samples (NIST SRM 1643d, 'trace elements in water') were analyzed with each set of samples (certified value $=20.5 \pm 3.8 \mu \mathrm{g} \mathrm{l}^{-1}$; measured value $=20.1 \pm 0.9 \mu \mathrm{g} \mathrm{l}^{-1}, \mathrm{n}=8$ ) and $\mathrm{Cu}$ concentrations were corrected for method blanks.

\section{RESULTS}

\section{Copper uptake from the dissolved phase}

The measurement of stable $\mathrm{Cu}$ accumulation in labacclimated copepods (fed low- $\mathrm{Cu}$ diatoms) was not sensitive enough to determine dissolved $\mathrm{Cu}$ uptake rates at $\mathrm{pCu}=14.79$ and $\mathrm{pCu}=12.79$ (Fig. 1). Copepods exposed to $\mathrm{pCu}=12.79$ and 14.79 showed an initial lack of significant accumulation of dissolved $\mathrm{Cu}$ followed by an apparent and transitory increase. Since the variability of $\mathrm{Cu}$ concentrations in copepods at different time points was similar to that within replicates 


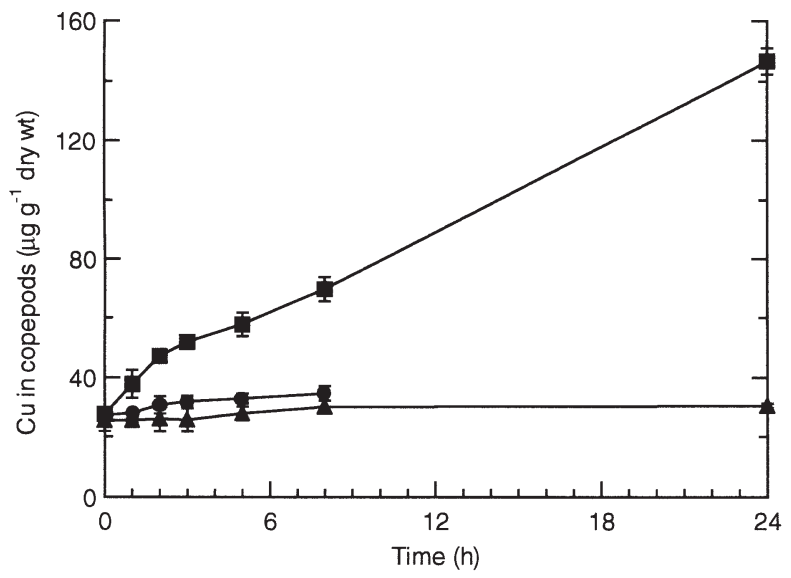

Fig. 1. Accumulation of dissolved $\mathrm{Cu}$ in copepods. Copepods were exposed to dissolved $\mathrm{Cu}$ at $\mathrm{pCu}=14.79(\boldsymbol{\Delta}), 12.79(\bullet)$, $9.79(\square)$, where $\mathrm{pCu}=-\log \left[\mathrm{Cu}^{2+}\right]$. Data points are means $\pm 1 \mathrm{SD}$

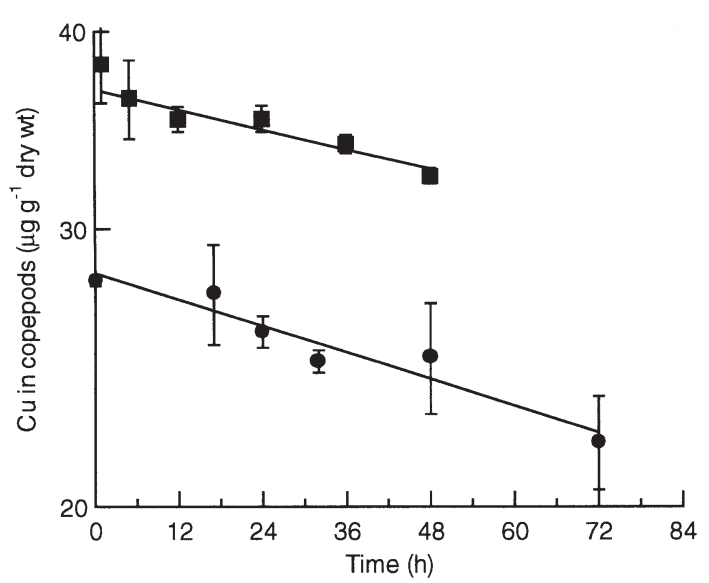

Fig. 2. Efflux of $\mathrm{Cu}$ from copepods fed diatoms grown with $10^{-12.79} \mathrm{M}$ free $\mathrm{Cu}(\mathbf{\square})$ and unacclimated Cheesequake Creek copepods $(\bullet)$. Data points are means $\pm 1 \mathrm{SD}$

sampled at the same time, no significant $\mathrm{Cu}$ accumulation rate could be determined. A significant $\mathrm{Cu}$ uptake rate was observed in copepods exposed to $\mathrm{pCu}=9.79$ ( $F=1097, \mathrm{p}<0.01)$. Dissolved $\mathrm{Cu}$ uptake in copepods exposed to $10^{-9.79} \mathrm{M}$ free $\mathrm{Cu}$ showed rapid uptake during the first $2 \mathrm{~h}$ followed by slower, constant accumulation thereafter (Fig. 1). Although EDTA rinsing results (Table 2) suggest that most of the accumulated $\mathrm{Cu}$ was internalized by the copepods, the initial rapid uptake during the first $2 \mathrm{~h}$ at $\mathrm{pCu}=9.79$ could be due to nonsteady-state surface accumulation (apparently not removable by $1 \mathrm{mM}$ EDTA). The $\mathrm{Cu}$ uptake rate at $\mathrm{pCu}=9.79$ was therefore calculated using data from $2 \mathrm{~h}$ onward. Very little mortality $(=5 \%)$ of copepods occurred during the $\mathrm{Cu}$ uptake experiments and was not corrected for in rate calculations. The free $\mathrm{Cu}$ specific uptake rate constant of dissolved $\mathrm{Cu}$ in cope- pods was estimated using the $\mathrm{Cu}$ uptake rate measured at $\mathrm{pCu}=9.79\left(110 \mu \mathrm{g} \mathrm{g}^{-1} \mathrm{~d}^{-1}\right)$ and was found to have a value of $1.1 \times 10^{4} \mathrm{lg}^{-1} \mathrm{~d}^{-1}$.

\section{Efflux rate of copper from copepods fed cultured diatoms and natural foods}

The depuration of $\mathrm{Cu}$ from both laboratory-fed (diatoms grown at $\mathrm{pCu}=12.79$ ) and unacclimated copepods was fairly slow, with a slightly faster release rate during the first $5 \mathrm{~h}$ from the cultured diatom-fed copepods (Fig. 2). By treating the copepods as a single-compartment organism, the slow phase of depuration, representing physiological loss of $\mathrm{Cu}$, can be used to determine the $\mathrm{Cu}$ efflux rate constant. Copper loss rate constants were calculated as the linear regression slopes of natural log-transformed depuration data. We used $\mathrm{Cu}$ loss data for 5-48 and 0-72 h to estimate the efflux rate constants of $\mathrm{Cu}$ in copepods fed cultured diatoms and unacclimated copepods, respectively. Copepod mortality was 10 to $15 \%$ during the efflux experiments and was not corrected for in loss rate calculations. Significant exponential loss rates were observed in the lab-fed $\left(0.056 \mathrm{~d}^{-1} ; F=34, \mathrm{p}<0.05\right)$ and unacclimated $\left(0.076 \mathrm{~d}^{-1}\right.$; $F=46, \mathrm{p}<0.05$ ) copepods and these were not significantly different from each other $(\mathrm{p}>0.99)$ by the TukeyKramer test of difference of slopes (Sokal \& Rohlf 1981). The maximum potential re-accumulation of $\mathrm{Cu}$ lost during the depuration experiments was evaluated using the dissolved $\mathrm{Cu}$ concentration that would have been obtained if all $\mathrm{Cu}$ lost from the copepods in $3 \mathrm{~d}$ was in the dissolved phase at the beginning of the depuration and the dissolved $\mathrm{Cu}$ uptake rate constant determined above. Based on bioassays with diatoms, the maximum total dissolved $\mathrm{Cu}$ the depuration copepods could have been exposed to corresponds to a free $\mathrm{Cu}$ of $<10^{-13.79} \mathrm{M}$ $\left(<10^{-6} \mu \mathrm{g} \mathrm{l}^{-1}\right)$. Thus the maximum dissolved $\mathrm{Cu}$ uptake rate in the depurating copepods could have been $<0.01 \mu \mathrm{g} \mathrm{g}^{-1} \mathrm{~d}^{-1}$. Since this is much lower than the observed minimum $\mathrm{Cu}$ loss rate $\left(1.2 \mu \mathrm{g} \mathrm{g}^{-1} \mathrm{~d}^{-1}\right)$, Cu recycling was considered unimportant in these experiments.

Table 2. Surface-adsorbed Cu (removable with 1 mM EDTA) in copepods exposed to dissolved $\mathrm{Cu}$ uptake media for $3 \mathrm{~h}$. Values are mean $\pm \mathrm{SD}(\mathrm{n}=3) \mathrm{Cu}$ concentrations with and without EDTA rinsing

\begin{tabular}{|rccc|}
\hline $\mathrm{pCu}$ & \multicolumn{2}{c|}{$\begin{array}{c}\text { Cu in copepods }\left(\mu \mathrm{g} \mathrm{g}^{-1} \text { dry wt) }\right. \\
\text { Rinsed with } \\
\text { seawater only }\end{array}$} & $\begin{array}{c}\text { Rinsed with } \\
\text { seawater plus } \\
\text { EDTA }\end{array}$ \\
$\begin{array}{rccc}\text { surface- } \\
\text { bound }\end{array}$ \\
\hline 14.79 & $26.0 \pm 0.8$ & $25.6 \pm 3.9$ & 0 \\
9.79 & $58.1 \pm 1.9$ & $51.8 \pm 0.1$ & 11 \\
\hline
\end{tabular}




\section{DISCUSSION}

\section{Accumulation of dissolved copper by copepods}

Copepods acclimated to a diet of diatoms grown at low free $\mathrm{Cu}(\mathrm{pCu}=14.79)$ accumulated dissolved $\mathrm{Cu}$ at $\mathrm{pCu}=9.79$, but not at $\mathrm{pCu}=14.79$ or 12.79. Loss of $\mathrm{Cu}$ accumulated by the copepods prior to collection or during acclimation may have obscured dissolved $\mathrm{Cu}$ uptake below a $\left[\mathrm{Cu}^{2+}\right]$ of $10^{-12.79} \mathrm{M}$. However, there does not appear to have been a rapid exchange of surface adsorbed $\mathrm{Cu}$ during the dissolved phase accumulation experiments since only 0 to $11 \%$ of $\mathrm{Cu}$ in the copepods was in a surface exchangeable pool (Table 2). The rapid accumulation of dissolved $\mathrm{Cu}$ in copepods at $\mathrm{pCu}=9.79$ was therefore mainly associated with internal tissues or strongly bound to the copepods' surfaces. At the highest exposure concentration, $\mathrm{Cu}$ accumulation in the copepods did not reach a steady-state in $24 \mathrm{~h}$ (Fig. 1), indicating an absence of $\mathrm{Cu}$ regulation over this time scale.

The free-Cu ion-specific rate constant of dissolved $\mathrm{Cu}$ accumulation in copepods measured here can be compared with those for other metals by conversion to a total metal-specific uptake rate constant with the ratio of free:total $\mathrm{Cu}$ in natural waters (total $\mathrm{Cu}$ values of the EDTA-buffered media are unrealistically high). The ratio of $\left[\mathrm{Cu}^{2+}\right]: \mathrm{Cu}_{\mathrm{T}}$ varies from $2.4 \times 10^{-5}$ in the surface waters of oligotrophic open ocean surface waters (Coale \& Bruland 1988) to $2.4 \times 10^{-3}$ in harbor surface waters (Moffett et al. 1997). Since our copepods were collected from a tributary of Raritan Bay, New Jersey, we used the measured speciation of dissolved $\mathrm{Cu}$ in Raritan Bay $(99.4 \%$ of total dissolved $\mathrm{Cu}$ is bound by organic ligands; Sunda et al. 1987) and an inorganic side reaction coefficient $\left(\alpha^{\prime}\right)$ of 13 (Byrne et al. 1988) to estimate a $\left[\mathrm{Cu}^{2+}\right]: \mathrm{Cu}_{\mathrm{T}}$ of $4.6 \times 10^{-4}$. The calculated total $\mathrm{Cu}$-specific uptake rate constant is therefore $5.1 \mathrm{l} \mathrm{g}^{-1}$ $\mathrm{d}^{-1}$ for these coastal waters. The uncertainty associated with this calculation notwithstanding, dissolved accumulation of $\mathrm{Cu}$ appears to be faster than that measured in estuarine copepods (Wang \& Fisher 1998) for $\mathrm{Cd}$ $\left(0.69 \mathrm{l} \mathrm{g}^{-1} \mathrm{~d}^{-1}\right)$, slightly slower than that for $\mathrm{Ag}\left(10 \mathrm{l} \mathrm{g}^{-1}\right.$ $\left.\mathrm{d}^{-1}\right)$ and similar to that for $\mathrm{Zn}\left(3.3 \mathrm{l} \mathrm{g}^{-1} \mathrm{~d}^{-1}\right)$.

\section{Efflux of copper from laboratory-fed and unacclimated copepods}

The efflux of $\mathrm{Cu}$ from copepods fed laboratorygrown diatoms showed a slightly faster rate within the first few hours than thereafter (Fig. 2), as was observed for other trace metals in laboratory-fed, marine copepods (Wang \& Fisher 1998). This initial loss, which may include $\mathrm{Cu}$ egestion, was not seen in the unacclimated copepods. Copper efflux rate constants for unacclimated copepods, which accumulated $\mathrm{Cu}$ from both the dissolved phase and food, and copepods fed cultured diatoms were not significantly different, indicating that the efflux rate of $\mathrm{Cu}$ is controlled primarily by copepod physiology and not by food type or route of exposure. The $\mathrm{Cu}$ efflux rate constants measured in this study $\left(0.06\right.$ to $\left.0.08 \mathrm{~d}^{-1}\right)$ are similar to that of the copepod Calanus hyperboreus in the Greenland Sea $\left(0.05 \mathrm{~d}^{-1}\right.$; Ritterhoff \& Zauke 1997a) and for $\mathrm{Zn}$ in Temora longicornis from the Long Island Sound $\left(0.08 \mathrm{~d}^{-1}\right.$; Wang \& Fisher 1998). They are, however, lower than those of $\mathrm{Ag}\left(0.3 \mathrm{~d}^{-1}\right), \mathrm{Cd}\left(0.3 \mathrm{~d}^{-1}\right)$, and Co $\left(0.3 \mathrm{~d}^{-1}\right)$ in T. longicornis (Wang \& Fisher 1998) and somewhat lower than those of $\mathrm{Pb}\left(0.23 \mathrm{~d}^{-1}\right)$ and $\mathrm{Zn}$ $\left(0.17 \mathrm{~d}^{-1}\right)$ in Greenland Sea Calanus hyperboreus (Ritterhoff \& Zauke 1997c). Based on these limited data, it appears that the efflux kinetics of metals in marine copepods do not vary greatly across taxa or among different metals. This is similar to what has been found for metal efflux in marine bivalves (Wang et al. 1996, Reinfelder et al. 1997). However, metal elimination rates in marine copepods are an order of magnitude higher than in marine bivalves $(0.01$ to $0.03 \mathrm{~d}^{-1}$; Wang et al. 1996, Reinfelder et al. 1997).

Our estimates of $\mathrm{Cu}$ efflux rate constants in copepods are at the low end of the range among the metals tested, indicating that assimilated $\mathrm{Cu}$ is associated with relatively slowly exchanging pools in these animals. The slow elimination of dissolved $\mathrm{Cu}$ from copepods may result from its strong tendency to bind protein (Bryan 1984). Copper is referred to as a 'borderline' metal that exhibits chemical reactivity with sulfur-, nitrogen-, and oxygen-bearing functional groups (Turner et al. 1981). The binding strength of $\mathrm{Cu}$ to sulfur-nitrogen ligands, such as cysteine or the metalloenzyme carbonic anhydrase, is greatest among the borderline metals which include $\mathrm{Cd}, \mathrm{Co}(\mathrm{II}), \mathrm{Fe}(\mathrm{II}), \mathrm{Ni}_{\text {, }}$ and $\mathrm{Zn}$ (Williams 1981). The slow turnover of $\mathrm{Cu}$ in copepods may also indicate a significant biological requirement for and/or regulation of this essential metal (see below) as has been noted for other marine invertebrates (Bryan 1984, Langston \& Spence 1995). Whether or not $\mathrm{Cu}$ is regulated or required by marine copepods, the remineralization of $\mathrm{Cu}$ by copepods via physiological turnover is sufficiently slow that it is not likely to be a significant pathway for the release of $\mathrm{Cu}$ from suspended particles into the dissolved phase.

\section{Kinetic model of the bioaccumulation of $\mathrm{Cu}$ in copepods}

Kinetic bioaccumulation models are bioenergetically based models in which the concentration of a metal in 

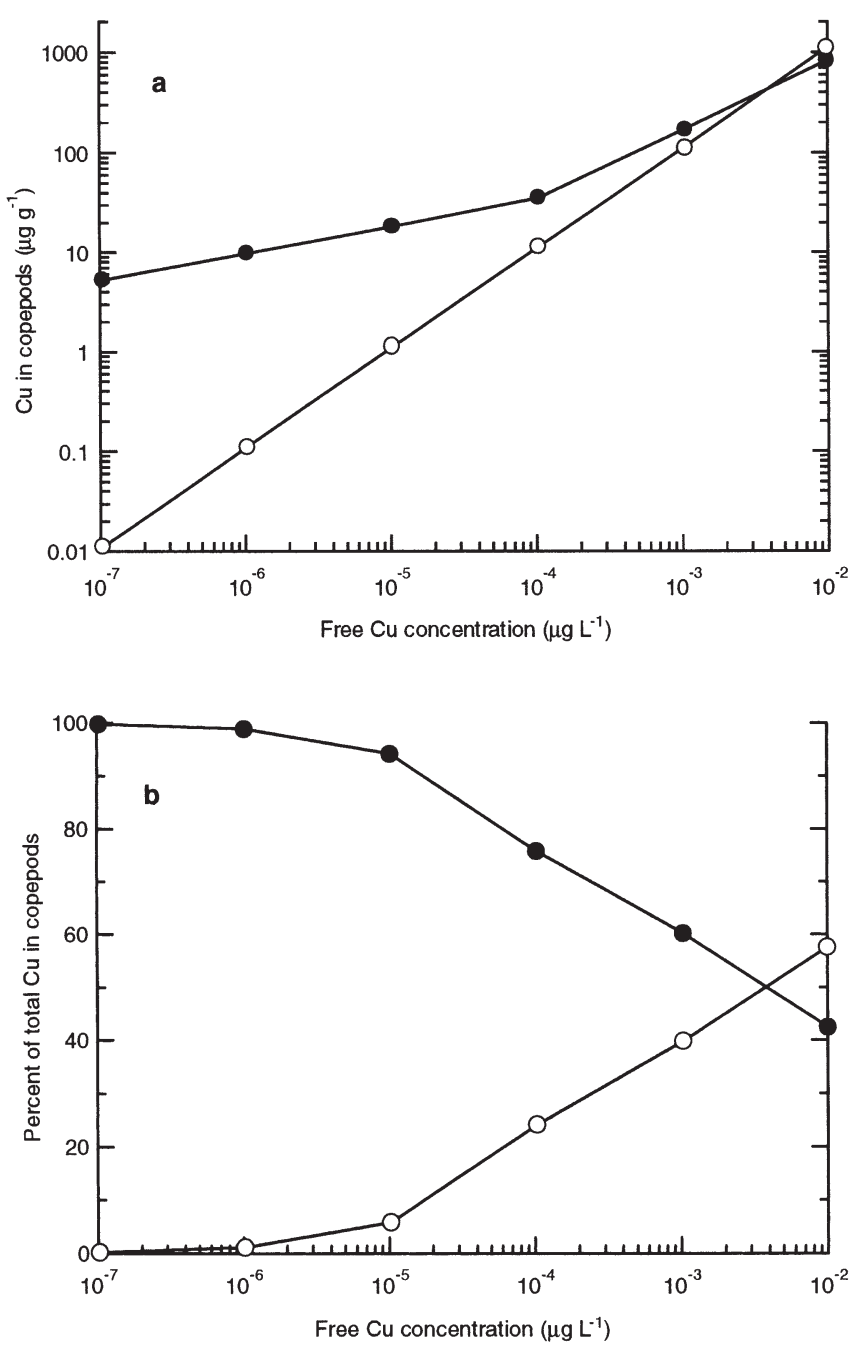

Fig. 3. (a) Model predicted $\mathrm{Cu}$ content and (b) percent total $\mathrm{Cu}$ in copepods attributable to accumulation from water (O) or food (

to low dissolved free- $\mathrm{Cu}$ ion concentrations $\left(\leq 10^{-4} \mu \mathrm{g}\right.$ $\mathrm{l}^{-1}$ or $10^{-11.79} \mathrm{M} \mathrm{Cu}^{2+}$ ). Thus, food accounts for $>75 \%$ of overall $\mathrm{Cu}$ accumulation at free- $\mathrm{Cu}$ ion concentrations ranging from $10^{-7}$ to $10^{-4} \mu \mathrm{g} \mathrm{l}^{-1}\left(10^{-14.79}\right.$ to $10^{-11.79} \mathrm{M}$, Fig. $3 \mathrm{~b}$ ). As a result of the relatively shallow slope of the diatom- $\mathrm{Cu}$-free- $\mathrm{Cu}$ concentration relationship (Chang \& Reinfelder 2000), over the 1000-fold increase in free- $\mathrm{Cu}$ concentration from $10^{-7}$ to $10^{-4} \mathrm{\mu g} \mathrm{l}^{-1}, \mathrm{Cu}$ accumulation in copepods from food increases by only a factor of 7 (Fig. 3a). Above a free-Cu ion concentration of $10^{-4} \mathrm{\mu g} \mathrm{l}^{-1}$, Cu accumulation from food increases more sharply with increasing free $\mathrm{Cu}$, but the fraction of total $\mathrm{Cu}$ accumulation from food decreased from 75 to $41 \%$ (Fig. $3 b$ ).

At free-Cu concentrations $>10^{-4} \mathrm{\mu g} \mathrm{l}^{-1}\left(10^{-11.79} \mathrm{M}\right)$, dissolved $\mathrm{Cu}$ is a significant $(>20 \%$ ) source of $\mathrm{Cu}$ to copepods (Fig. 3). It is well recognized that organic complexation dominates the speciation of $\mathrm{Cu}$ in coastal and oceanic surface waters and buffers the concentration of free dissolved $\mathrm{Cu}$ (Coale \& Bruland 1988, 1990, Kozelka \& Bruland 1998). However, small increases in total dissolved $\mathrm{Cu}$ can titrate $\mathrm{Cu}$-complexing organic ligands, resulting in large increases in free-dissolved$\mathrm{Cu}$ ion concentrations (Moffett 1995, Moffett et al. 1997). For example, free-Cu ion concentrations in polluted harbors can reach as high as $10^{-10} \mathrm{M}$ (Ahner et al. 1997). Under such conditions, there could be a greater contribution of the dissolved phase than trophic transfer to $\mathrm{Cu}$ accumulation in copepods, especially if the increase in dissolved $\mathrm{Cu}$ occurs over a time scale that is shorter than that required for prey phytoplankton to reach steady-state with the dissolved phase. Eventually, elevated free-Cu concentrations will lead to higher phytoplankton $\mathrm{Cu}$ concentrations and higher $\mathrm{Cu}$ accumulation in consumer organisms such as copepods via trophic transfer.

Sunda et al. (1987) suggested that the concentration of free $\mathrm{Cu}$ in some polluted estuarine waters $\left(\sim 10^{-11} \mathrm{M}\right)$ is high enough to affect the survival and reproduction of copepods. We observed very little mortality of copepods $(\sim 5 \%)$ during $24 \mathrm{~h}$ exposure to high free-Cu ion concentrations $(\mathrm{pCu}=9.79)$, which indicates that toxic effects on the survival of copepods may not result from short-term dissolved $\mathrm{Cu}$ exposures. Copper toxicity in copepods may result from chronic exposure to high dissolved $\mathrm{Cu}$ or from $\mathrm{Cu}$ obtained via trophic transfer as has been shown for $\mathrm{Ag}$ and $\mathrm{Cd}$ (Hook \& Fisher 2001).

The importance of trophic transfer to the accumulation of metals (most notably Se and $\mathrm{Zn}$ ) has been demonstrated in a number of marine herbivores (Wang et al. 1996, Fisher et al. 2000). The present results show that trophic transfer is also of major importance to the accumulation of $\mathrm{Cu}$ in marine copepods. This is so because the bioaccumulation of $\mathrm{Cu}$ in copepods is characterized by low efflux rates, a relatively high $\mathrm{AE}$, and a negligible contribution of dissolved uptake at free- $\mathrm{Cu}$ ion concentrations that are typical of most natural waters.

Acknowledgements. This work was supported by Hatch/ McIntyre-Stennis grant 07142 and NJ SeaGrant project R/E2002 to J.R.R. We thank 3 anonymous reviewers for their comments.

\section{LITERATURE CITED}

Ahner BA, Morel FMM, Moffett JW (1997) Trace metal control of phytochelatin production in coastal waters. Limnol Oceanogr 42:601-608

Anderson DM, Morel FMM (1978) Copper sensitivity of Gonyaulax tamarensis. Limnol Oceanogr 23:283-295

Bryan GW (1984) Pollution due to heavy metals and their 
compounds. In: Kinne O (ed) Marine ecology, Vol 5. John Wiley \& Sons, Chichester, p 1289-1430

Byrne RH, Lump LR, Cantrell KJ (1988) The influence of temperature and $\mathrm{pH}$ on trace metal speciation in seawater. Mar Chem 25:163-181

Chang SI, Reinfelder JR (2000) Bioaccumulation, subcellular distribution, and trophic transfer of copper in a coastal marine diatom. Environ Sci Technol 34:4931-4935

Coale KH, Bruland KW (1988) Copper complexation in the northeast Pacific. Limnol Oceanogr 33:1084-1101

Coale KH, Bruland KW (1990) Spatial and temporal variability in copper complexation in the North Pacific. Deep-Sea Res 47:317-336

Depledge $\mathrm{MH}$, Bjerregaard P (1989) Haemolymph protein composition and copper levels in decapod crustaceans. Helgol Meeresunters 43:207-223

Fisher NS, Reinfelder JR (1995) The trophic transfer of metals in marine systems. In: Tessier A, Turner DR (eds) Metal speciation and bioavailability in aquatic systems. IUPAC, Wiley, Chichester, p 363-406

Fisher NS, Stupakoff I, Sañudo-Wilhelmy S, Wang WX, Teyssié JL, Fowler SW, Crusius J (2000) Trace metals in marine copepods: a field test of a bioaccumulation model coupled to laboratory uptake kinetics data. Mar Ecol Prog Ser 194:211-218

Hook SE, Fisher NS (2001) Reproductive toxicity of metals in calanoid copepods. Mar Biol 138:1131-1140

Kozelka PB, Bruland KW (1998) Chemical speciation of dissolved $\mathrm{Cu}, \mathrm{Zn}, \mathrm{Cd}, \mathrm{Pb}$ in Narragansett Bay, Rhode Island. Mar Chem 60:267-282

Landrum PF, Lee H, Lydy MJ (1992) Toxicokinetics in aquatic systems: model comparisons and use in hazard assessment. Environ Toxicol Chem 11:1709-1725

Langston WJ, Spence SK (1995) Biological factors involved in metal concentrations observed in aquatic organisms. In: Tessier A, Turner DR (eds) Metal speciation and bioavailability in aquatic systems. Wiley, Chichester, p 407-478

Lee BG, Griscom SB, Lee JS, Choi HJ, Koh CH, Luoma SN, Fisher NS (2000) Influence of dietary uptake and acidvolatile sulfide on bioavailability of metals to sedimentdwelling organisms. Science 287:282-284

Lonsdale DJ, Cosper EM, Kim WS, Doall M, Divadeenam A, Jonasdottir SH (1996) Food web interactions in the plankton of Long Island bays, with preliminary observations on brown tide effects. Mar Ecol Prog Ser 134:247-263

Luoma SN, Johns C, Fisher NS, Steinberg NA, Oremland RS, Reinfelder JR (1992) Determination of selenium bioavailability to a benthic bivalve from particulate and solute pathways. Environ Sci Technol 26:485-491

Moffett JW (1995) The spatial and temporal variability of copper complexation by strong organic ligands in the Sargasso Sea. Deep-Sea Res 42:1273-1295

Moffett JW, Brand LE, Croot PL, Barbeau KA (1997) Cu speciation and cyanobacterial distribution in harbors subject to anthropogenic Cu inputs. Limnol Oceanogr 42:789-799

Munger C, Hare L (1997) Relative importance of water and food as cadmium sources to an aquatic insect (Chaoborus puntipennis): implications for predicting Cd bioaccumulation in nature. Environ Sci Technol 31:891-895

Price NM, Harrison GI, Herring JG, Hudson RJ, Nirel PM, Palenik B, Morel FMM (1988/89) Preparation and chemistry of the artificial algal culture medium Aquil. Biol Oceanogr 6:443-461

Reinfelder JR, Wang WX, Luoma SN, Fisher NS (1997) Assimilation efficiencies and turnover rates of trace elements in marine bivalves: a comparison of oyster, clams, and mussels. Mar Biol 129:443-452

Reinfelder JR, Fisher NS, Luoma SN, Nichols JW, Wang WX (1998) Trace element trophic transfer in aquatic organisms: a critique of the kinetic model approach. Sci Total Environ 219:117-135

Ritterhoff J, Zauke GP (1997a) Evaluation of trace metal toxicokinetics in Greenland Sea copepod and amphipod collectives from semi-static experiments on board ship. Polar Biol 17:242-250

Ritterhoff J, Zauke GP (1997b) Trace metals in field samples of zooplankton from the Fram Strait and the Greenland Sea. Sci Total Environ 199:255-270

Ritterhoff J, Zauke GP (1997c) Bioaccumulation of trace metals in Greenland Sea copepod and amphipod collectives on board ship: verification of toxicokinetic model parameters. Aquat Toxicol 40:63-78

Sanders BM, Jenkins KD, Sunda WG, Costlow JD (1983) Free cupric ion activity in seawater: effects on metallothionein and growth in crab larvae. Science 222:53-55

Sharp AA, Stearns DE (1997) Sublethal effects of cupric ion activity on the grazing behaviour of three calanoid copepods. Mar Pollut Bull 34:1041-1048

Sokal RR, Rohlf FJ (1981) Biometry, 2nd edn. Freeman, San Francisco

Sunda WG, Guillard RRL (1976) The relationship between cupric ion activity and the toxicity of copper to phytoplankton. J Mar Res 34:511-529

Sunda WG, Huntsman SA (1983) The effect of competitive interactions between manganese and copper on cellular manganese and growth in estuarine and oceanic species of the diatom Thalassiosira. Limnol Oceanogr 28:924-934

Sunda WG, Huntsman SA (1995) Regulation of copper concentration in the oceanic nutricline by phytoplankton uptake and regeneration cycles. Limnol Oceanogr 40:132-137

Sunda WG, Tester PA, Huntsman SA (1987) Effects of cupric and zinc ion activities on the survival and reproduction of marine copepods. Mar Biol 94:203-210

Thomann RV, Mahony JE, Mueller R (1995) Steady-state model of biota sediment accumulation factor for metals in two marine bivalves. Environ Toxicol Chem 14:1989-1998

Turner DR, Whitfield M, Dickson AG (1981) The equilibrium speciation of dissolved components in freshwater and seawater at $25^{\circ} \mathrm{C}$ and $1 \mathrm{~atm}$ pressure. Geochim Cosmochim Acta 45:855-881

Wang WX, Fisher NS (1997) Modeling metal bioavailability for marine mussels. Rev Environ Contam Toxicol 151: 39-65

Wang WX, Fisher NS (1998) Accumulation of trace elements in a marine copepod. Limnol Oceanogr 43:273-283

Wang WX, Fisher NS, Luoma SN (1996) Kinetic determinations of trace element bioaccumulation in the mussel Mytilus edulis. Mar Ecol Prog Ser 140:91-113

Westall JC, Zachary JL, Morel FMM (1976) MINEQL, Computer program of thermodynamic calculation. Tech Note 18, RM Parsons Laboratory, MIT, Cambridge, MA

White SL, Rainbow PS (1985) On the metabolic requirement for $\mathrm{Cu}$ and $\mathrm{Zn}$ in molluscs and crustaceans. Mar Environ Res 160:215-229

Williams RJP (1981) Physico-chemical aspects of inorganic element transfer through membranes. Phil Trans R Soc Lond B Biol Sci 294:57-74

Zamuda CD, Sunda WG (1982) Bioavailability of dissolved Cu to the American oyster Crassostrea virginica. I. Importance of chemical speciation. Mar Biol 66:77-82 